\title{
MULTIDENTATE TEREPHTHALAMIDATE AND HYDROXYPYRIDONATE LIGANDS: TOWARDS NEW ORALLY ACTIVE CHELATORS
}

\author{
Rebecca J. Abergel ${ }^{1}$ and Kenneth N. Raymond ${ }^{1,2}$ \\ ${ }^{I}$ Chemical Sciences Division, Glenn T. Seaborg Center, Lawrence Berkeley National \\ Laboratory, Berkeley, CA 94720 USA \\ ${ }^{2}$ Department of Chemistry, University of California, Berkeley, CA 94720 USA
}

\begin{abstract}
DISCLAIMER
This document was prepared as an account of work sponsored by the United States Government. While this document is believed to contain correct information, neither the United States Government nor any agency thereof, nor the Regents of the University of California, nor any of their employees, makes any warranty, express or implied, or assumes any legal responsibility for the accuracy, completeness, or usefulness of any information, apparatus, product, or process disclosed, or represents that its use would not infringe privately owned rights. Reference herein to any specific commercial product, process, or service by its trade name, trademark, manufacturer, or otherwise, does not necessarily constitute or imply its endorsement, recommendation, or favoring by the United States Government or any agency thereof, or the Regents of the University of California. The views and opinions of authors expressed herein do not necessarily state or reflect those of the United States Government or any agency thereof or the Regents of the University of California.
\end{abstract}

\section{FUNDING}

This work was supported by National Institutes of Health grants 1RC2AI087604-01 (KNR, RJA) and DK057814 (KNR), a Cooley's Anemia Foundation Young Investigator Fellowship (RJA), and the Director, Office of Science, Office of Basic Energy Sciences, Division of Chemical Sciences, Geosciences, and Biosciences of the U.S. Department of Energy at Lawrence Berkeley National Laboratory under Contract No. DE-AC02-05CH11231. 
Abstract. The limitations of current therapies for the treatment of iron overload or radioisotope contamination have stimulated efforts to develop new orally bioavailable iron and actinide chelators. Siderophore-inspired tetradentate, hexadentate and octadentate terephthalamidate and hydroxypyridonate ligands were evaluated in vivo as selective and efficacious iron or actinide chelating agents, with several metal loading and ligand assessment procedures, using ${ }^{59} \mathrm{Fe},{ }^{238} \mathrm{Pu}$, and ${ }^{241} \mathrm{Am}$ as radioactive tracers. The compounds presented in this study were compared to commercially available therapeutic sequestering agents (desferrioxamine for iron and diethylenetriaminepentaacetic acid for actinides) and are unrivaled in terms of affinity, selectivity and decorporation efficacy, which attests to the fact that high metal affinity may overcome the low bioavailability properties commonly associated to multidenticity.

Key words. Iron overload, Actinide contamination, Hydroxypyridonate ligands, Terephthalamidate ligands, Chelating agents, Chelation therapy. 


\section{INTRODUCTION}

Chelation therapy is the only therapeutic approach that leads to enhanced metal excretion in patients with iron-overload conditions such as $\beta$-thalassemia or in patients contaminated with harmful internalized radionuclides such as actinides (1-4). While continuous infusions of the natural siderophore Desferrioxamine (DFO, Figure 1) have significantly raised the life expectancy of patients with transfusional iron overload over the last four decades, the leading cause of death in thalassemia major remains cardiac disease from myocardial iron deposition and the administration regimen of DFO often results in poor compliance (5). Similarly, diethylenetriaminepentaacetic acid (DTPA, administered as $\mathrm{CaNa}_{3}-$ or $\mathrm{ZnNa}_{3}-\mathrm{DTPA}$, Figure 2), the only approved actinide decorporation agent $(2,6)$, can reduce the acute radiation damage, late radiation effects and chemical toxicity caused by internalized actinides. However, DTPA is not active when administered orally and is not suitable for the simultaneous long-term treatment of a large population. Extensive research efforts have therefore been dedicated to the development of low-cost orally active iron and actinide chelators with high efficacy and low toxicity profiles.

The fundamental hypothesis underlying our approach to the development of new chelators is that thermodynamic stability of the corresponding metal complexes is a necessary requirement. The relative complexing abilities of iron chelating agents that vary in denticity (degree to which they individually satisfy the six coordination requirements of iron) are shown in Figure 1. While DFO remains the predominantly used iron chelator, its thermodynamic stability is not matched by oral activity (5), In contrast, the bidentate chelator Deferiprone (L1, Figure 1) is relatively inexpensive and orally active $(4,7,8)$. However, L1 has a very rapid drop-off in stability with concentration (Figure 1), which requires usage at a high dose and thus can be related to serious 
toxicity problems. The tridentate chelator Deferasirox (ICL670A), recently introduced by Novartis (9), has moderate stability at low concentrations, forming a two to one complex with ferric ion. It is orally effective but has also been associated with a number of toxicity problems and is costly $(4,8,10)$. Our hypothesis remains that any tridentate or bidentate ligand will be problematic because of the relatively high concentrations required by second- or third-order dependence on ligand concentration for a fully formed ferric complex. Incompletely complexed iron, which may be Fenton-reactive, may also contribute to toxic side effects by hydroxyl radical catalyzed oxidative injury.

\section{[Figure 1]}

Similarly, multidentate chelators will fulfill the high coordination requirements of actinides such as $\mathrm{Pu}(\mathrm{IV})$ and $\mathrm{Am}(\mathrm{III})$, and will form the most stable complexes. Therefore, our research is focused on the development of high-denticity ligands (hexadentate and tetradentate for iron; octadentate and tetradentate for actinides) as new therapeutic chelators. Because high-denticity ligands are inherently large molecules, few multidentate compounds have been designed and envisaged as potential orally active chelators (11-13). However, thermodynamic complex stability, fast kinetics of complexation, lipophilicity and therapeutic index are other major parameters that determine the efficacy of a ligand when given orally (14). Examples of prospective orally active therapeutics with large molecular sizes are presented herein.

All ligands include two, three, or four bidentate metal-binding groups, linked to polyamine scaffolds through amide functionalities, to form tetradentate, hexadentate or octadentate structures, respectively. Based on previous thermodynamic and biological studies, the 2,3dihydroxyterephthalamide (TAM) metal-binding moiety was used in ligands targeting iron (15, 16), while 1,2-hydroxypyridinone (1,2-HOPO) and methyl-3,2-hydroxypyridinone (Me-3,2- 
HOPO) units were incorporated into ligands targeting actinides $(2,6)$. In this work, the effect of denticity on iron removal efficacy was investigated using three TAM-based iron chelators: the linear tetradentate ligand 5-LIO(TAMmeg), the linear hexadentate ligand 5$\mathrm{LIO}_{2}(\mathrm{TAM})(\text { TAMmeg) })_{2}$, and the tripodal hexadentate ligand TREN(TAMmeg) (Figure 1). In parallel, actinide removal studies performed with the tetradentate ligand 5-LIO(Me-3,2-HOPO) and the octadentate structure 3,4,3-LI(1,2-HOPO) (Figure 2) were used to compare the efficacy of these large molecules when administered by injection or orally.

\section{[Figure 2]}

\section{MATERIALS AND METHODS}

General. All chemicals were obtained from commercial suppliers and were used as received. The ligands 5-LIO(TAMmeg) (17), 5-LIO 2 (TAM)(TAMmeg) 2 (15), TREN(TAMmeg) (18), 5LIO(Me-3,2-HOPO) (19), and 3,4,3-LI(1,2-HOPO) (19) were prepared and characterized according to procedures described in the designated references. Desferal ${ }^{\circledR}$, the mesylate salt of DFO was obtained from Ciba-Geigy Ltd.

Metal and Ligand Solutions. The ${ }^{59} \mathrm{Fe}\left({ }^{238} \mathrm{Pu}\right.$ and ${ }^{241} \mathrm{Am}$, respectively) excretion rates and pathways promoted by the test ligands were investigated in comparison to DFO $\left(\mathrm{CaNA}_{3}-\mathrm{DTPA}\right.$, respectively) and saline-injected control animals. Labeled ${ }^{59} \mathrm{Fe}$-transferrin $\left({ }^{59} \mathrm{Fe}-\mathrm{Tf}\right)$ was prepared by incubating ${ }^{59} \mathrm{Fe}$-citrate (molar ratio citrate:Fe $=10$ ) with fresh mouse plasma. Chromatography on Sephadex G-25 gel filtration columns $(1.5 \mathrm{~cm} \times 30 \mathrm{~cm}$, tris-saline buffer elution, $\mathrm{pH}$ 7.4) showed quantitative ${ }^{59} \mathrm{Fe}$ elution with the plasma proteins (fractions number 20 to 40 ), indicative of transferrin binding. A fresh batch of ${ }^{59} \mathrm{Fe}$-Tf was prepared for each study, doses consisted in $0.2 \mathrm{~mL}$ aliquots of labeled plasma containing $\sim 0.25 \mu \mathrm{Ci}$ of ${ }^{59} \mathrm{Fe}$. Actinide 
doses consisted in $0.2 \mathrm{~mL}$ aliquots of actinide chloride solutions $\left(\sim 0.025 \mu \mathrm{Ci}\right.$ of ${ }^{238} \mathrm{Pu}$ or $\left.{ }^{241} \mathrm{Am}\right)$ in $0.008 \mathrm{M}$ sodium citrate and $0.14 \mathrm{M} \mathrm{NaCl}, \mathrm{pH}$ 4. Ligand solutions were prepared such that the

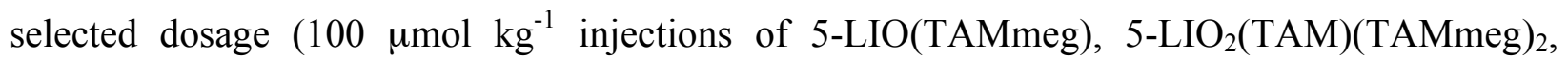
TREN(TAMmeg), and DFO; $10 \mu \mathrm{mol} \mathrm{kg} \mathrm{kg}^{-1}$ injection and $30 \mu \mathrm{mol} \mathrm{kg} \mathrm{kg}^{-1}$ oral administration of 3,4,3-LI(1,2-HOPO); $30 \mu \mathrm{mol} \mathrm{kg}{ }^{-1}$ injection and $100 \mu \mathrm{mol} \mathrm{kg}{ }^{-1}$ oral administration of 5LIO(Me-3,2-HOPO)) was contained in $0.5 \mathrm{~mL}$ of $0.14 \mathrm{M} \mathrm{NaCl}$, the $\mathrm{pH}$ being adjusted to 7.4-8.4 with $1 \mathrm{~N} \mathrm{NaOH}$.

In Vivo Metal Removal Studies. The animals used were young adult female Swiss-Webster mice (87 \pm 9 days old, $34 \pm 2 \mathrm{~g}$ ). Gross body and tissue compositions, plasma, extracellular fluid, and red cell volumes of the whole body, major tissues and organs of these mice (intact or bled 25 to $40 \%$ of their total blood volume) have been determined (20). All experiments using ${ }^{59} \mathrm{Fe},{ }^{238} \mathrm{Pu}$ or ${ }^{241} \mathrm{Am}$ tracers were managed as metabolic balance studies, in which blood, all tissues, and excreta were analyzed for the appropriate tracer. The methods of sampling, sample preparation and radioanalysis have been described in details previously $(21,22)$. Those methods provide quantitative measurements of the radioactivity in the biological samples, and material recoveries are about $95 \%$, on average, of the amount injected. Under isoflurane anesthesia, groups of five mice were injected in a lateral tail vein with $0.2 \mathrm{~mL}$ metal tracer doses. Ligands were administered at $30 \mathrm{~min}$ or $1 \mathrm{~h}$ after the metal, for iron or actinide removal studies, respectively, by intraperitoneal (ip) injection to normally fed mice or orally (gastric intubation) to mice that had been fasted for $16 \mathrm{~h}$. Each 5-mouse group was housed together in a plastic stock cage lined with a $0.5 \mathrm{~cm}$ layer of highly absorbent low-ash pelleted cellulose bedding (ALPHA-dri ${ }^{\circledR}$ ) for separation of urine and feces. All mice were given water and food ab libitum (for fasted mice, food became available at $4 \mathrm{~h}$ after the metal injection), and were euthanized by cervical 
dislocation at $24 \mathrm{~h}$ after the metal injection. Samples included whole blood, plasma, liver, kidneys, spleen, gastrointestinal (GI) tract plus contents (divided at the ileocecal junction into upper and lower GI tract), residual carcass, urine (sorbed to the cellulose bedding) and passed feces. Samples were dried at $100{ }^{\circ} \mathrm{C}$ and dry ashed at $575{ }^{\circ} \mathrm{C}$. The ashed samples were dissolved in dilute $\mathrm{HNO}_{3}$. The blood, plasma, and small tissue samples, which were dried, ashed and dissolved in their glass counting vials, and weight aliquots of the dissolved large samples (bulk soft tissue, skeleton, urine, feces) were mixed with Ultimagold ${ }^{\circledR}$ for detection of the radiotracers by scintillation counting. Details of autopsy procedures, tissue and excreta collection and processing, as well as radioactivity measurements (liquid scintillation counting, Packard TriCarb model B4430) and methods of data reduction have been previously reported $(21,22)$.

\section{RESULTS AND DISCUSSION}

Efficacy of TAM-Containing Ligands for Promoting in vivo ${ }^{59} \mathrm{Fe}$ Excretion. To evaluate the efficacy of the tested TAM-containing ligands at promoting iron decorporation, the designed experimental protocol used a ${ }^{59} \mathrm{Fe}$ radiolabel administered as ${ }^{59} \mathrm{Fe}$-transferrin $\left({ }^{59} \mathrm{Fe}-\mathrm{Tf}\right)$ in mouse plasma. ${ }^{59} \mathrm{Fe}-\mathrm{Tf}$ transiently labels circulating transferrin and, after its clearance from plasma, red cells and hepatocytes. This protocol permits the determination of the chelators' capability to bind and enhance the excretion of iron derived from circulating ${ }^{59} \mathrm{Fe}-\mathrm{Tf}$ as it is transported from the GI tracts and sites of red cell catabolism (spleen) to sites of iron utilization (bone marrow) or storage (liver); it reflects the chelator's potential to consistently remove iron in vivo. The ${ }^{59} \mathrm{Fe}-\mathrm{Tf}$ tracer was injected intravenously (iv), and ligands $\left(100 \mu \mathrm{mol} \mathrm{kg}^{-1}\right)$ were injected ip $30 \mathrm{~min}$ later. Mice were euthanized at $24 \mathrm{~h}$, and blood, tissues, and excreta were radioanalyzed for ${ }^{59} \mathrm{Fe}$. The efficacies of the three TAM-containing ligands, 5-LIO(TAMmeg), 5- $\mathrm{LIO}_{2}(\mathrm{TAM})(\mathrm{TAMmeg})_{2}$ 
and TREN(TAMmeg), for in vivo chelation of ${ }^{59} \mathrm{Fe}$ injected iv as ${ }^{59} \mathrm{Fe}-\mathrm{Tf}$ were compared with DFO and untreated controls (Table 1). The 24-h excretion of ${ }^{59} \mathrm{Fe}$ promoted by these ligands in this protocol is illustrated in Figure 3. All three ligands promoted significantly more fecal and total ${ }^{59} \mathrm{Fe}$ excretion than DFO and the controls, and markedly reduced ${ }^{59} \mathrm{Fe}$ in the liver, kidneys and whole body as compared to controls. In addition, the ${ }^{59} \mathrm{Fe}$ content in the liver and whole body of mice treated with the hexadentate ligands, 5- $\mathrm{LIO}_{2}(\mathrm{TAM})(\mathrm{TAMmeg})_{2}$ and TREN(TAMmeg), was considerably lower than that in mice treated with DFO. The three TAMcontaining ligands promoted ${ }^{59} \mathrm{Fe}$ decorporation similarly, trough fecal excretion predominantly ( $\sim 80 \%$ and $\sim 75 \%$ of the total excretion for the tetradentate and hexadentate ligands, respectively). However, both hexadentate ligands were significantly more efficacious than the tetradentate ligand, as treatment with 5- $\mathrm{LIO}_{2}(\mathrm{TAM})(\mathrm{TAMmeg})_{2}$ and TREN(TAMmeg) resulted in $39 \%$ and $33 \%$, respectively, more total ${ }^{59} \mathrm{Fe}$ excretion than with 5 -LIO(TAMmeg).

\section{[Table 1, Figure 3]}

\section{Efficacy of HOPO-Containing Ligands for Promoting in vivo ${ }^{238} \mathrm{Pu}$ and ${ }^{241} \mathrm{Am}$}

Excretion. To evaluate the efficacy of the tested HOPO-containing ligands at promoting plutonium and americium decorporation, the designed experimental protocol used ${ }^{238} \mathrm{Pu}$ and ${ }^{241} \mathrm{Am}$ radiolabels administered iv as chloride solutions in $0.008 \mathrm{M}$ sodium citrate and $0.14 \mathrm{M}$ $\mathrm{NaCl}, \mathrm{pH}$ 4. The ligands were administered $1 \mathrm{~h}$ later, by ip injection or orally, mice were euthanized $24 \mathrm{~h}$ later, and blood, tissues, and excreta were radioanalyzed for ${ }^{238} \mathrm{Pu}$ or ${ }^{241} \mathrm{Am}$. Ligand concentrations were selected based on the ligand denticity and previous studies (2). The efficacies of the two HOPO-containing ligands, 5-LIO(Me-3,2-HOPO) and 3,4,3-LI(1,2-HOPO), for in vivo chelation of ${ }^{238} \mathrm{Pu}$ or ${ }^{241} \mathrm{Am}$ were compared with $\mathrm{CaNa}_{3}$-DTPA, untreated controls 
(Tables 2 and 3), and other dosages previously reported (19). The 24-h actinide excretion promoted by these ligands in this protocol is illustrated in Figures 4 and 5. At all concentrations tested, both experimental ligands promoted significantly more fecal and total actinide (for both ${ }^{238} \mathrm{Pu}$ and $\left.{ }^{241} \mathrm{Am}\right)$ excretion than $\mathrm{CaNa}_{3}-\mathrm{DTPA}$ and the controls, and markedly reduced actinide content in the liver, kidneys, soft tissues and whole body as compared to controls. In addition, the actinide content in the liver and whole body of mice treated with the HOPO-containing ligands was considerably lower than that in mice treated with $\mathrm{CaNa}_{3}$-DTPA. In contrary to $\mathrm{CaNa}_{3}-\mathrm{DTPA}$, both 5-LIO(Me-3,2-HOPO) and 3,4,3-LI(1,2-HOPO) promoted ${ }^{238} \mathrm{Pu}$ and ${ }^{241} \mathrm{Am}$ decorporation trough the same predominant fecal excretion pathway $(\sim 75 \%$ of the total excretion). However, when ligands were administered at the same concentration $\left(30 \mu \mathrm{mol} \mathrm{kg}{ }^{-1}\right.$ ip and $100 \mu \mathrm{mol} \mathrm{kg}{ }^{-1}$ oral), more actinide total excretion was observed with the octadentate structure 3,4,3-LI(1,2-HOPO). While the efficacies of the two experimental ligands administered by ip injection were independent of the tested doses (10 and $30 \mu \mathrm{mol} \mathrm{kg}{ }^{-1}$ for 3,4,3-LI(1,2HOPO); 30 and $100 \mu \mathrm{mol} \mathrm{kg}{ }^{-1}$ for 5-LIO(Me-3,2-HOPO)), increasing the ligand doses for oral administration (from 30 to $100 \mu \mathrm{mol} \mathrm{kg}{ }^{-1}$ for 3,4,3-LI(1,2-HOPO); from 100 to $200 \mu \mathrm{mol} \mathrm{kg}^{-1}$ for 5-LIO(Me-3,2-HOPO)) considerably enhanced ${ }^{238} \mathrm{Pu}(30 \%$ and $42 \%$ increase for $3,4,3-$ $\mathrm{LI}(1,2-\mathrm{HOPO})$ and 5-LIO(Me-3,2-HOPO), respectively) and ${ }^{241} \mathrm{Am}$ (66\% and 18\% increase for 3,4,3-LI(1,2-HOPO) and 5-LIO(Me-3,2-HOPO), respectively) total excretion. Finally, at corresponding ligand concentrations $\left(30 \mu \mathrm{mol} \mathrm{kg}{ }^{-1}\right.$ for 3,4,3-LI(1,2-HOPO); $100 \mu \mathrm{mol} \mathrm{kg}{ }^{-1}$ for 5$\mathrm{LIO}(\mathrm{Me}-3,2-\mathrm{HOPO}))$, ip injections resulted in higher levels of ${ }^{238} \mathrm{Pu}(35 \%$ and $64 \%$ increase for 3,4,3-LI(1,2-HOPO) and 5-LIO(Me-3,2-HOPO), respectively) and ${ }^{241} \mathrm{Am}$ (126\% and 36\% increase for 3,4,3-LI(1,2-HOPO) and 5-LIO(Me-3,2-HOPO), respectively) total excretion, as compared to oral treatments. Nevertheless, similar high total excretion levels could be reached 
after administration of increased oral doses $\left(100 \mu \mathrm{mol} \mathrm{kg}{ }^{-1}\right.$ for 3,4,3-LI(1,2-HOPO); $200 \mu \mathrm{mol}$ $\mathrm{kg}^{-1}$ for 5-LIO(Me-3,2-HOPO)).

\section{[Tables 2 and 3, Figures 4 and 5]}

Effect of Ligand Denticity on Efficacy and Oral Availability. To exert its pharmacological effect, a chelating agent must not only be able to cross biological membranes and access the desired target sites, such as the liver, at sufficient concentration; it must also be able to compete with endogenous ligands and proteins by forming highly stable complexes of the targeted metal ion. The $\mathrm{pM}$ value is a common parameter used to compare ligands of varying acidity and denticity; it indicates the negative log value of the free metal ion concentration at $\mathrm{pH} 7.4,1 \mu \mathrm{M}$ [Metal], and $10 \mu \mathrm{M}$ [Ligand]. A chelator that exhibits a pM value higher than those of chelating bioligands such as transferrin $\left(\mathrm{pM}\left(\mathrm{Fe}^{\mathrm{III}}\right)=23.6\right)(23)$ will likely be efficient at removing the metal ion in vivo, and more so than other chelating agents with lower $\mathrm{pM}$ values. As shown in Figure 1 for current iron chelators and experimental ligands, the $\mathrm{pM}$ value generally increases with denticity. While stability constants and $\mathrm{pM}$ values have not been determined for all the experimental ligands used in this work, a primary goal of the studies described here was to verify that the increase in complex stability obtained with higher-denticity ligands containing comparable metal-binding units translates into an increase in in vivo metal removal efficacy. When injected at the same dose levels, both hexadentate ligands 5- $\mathrm{LIO}_{2}(\mathrm{TAM})(\mathrm{TAMmeg})_{2}$ and TREN(TAMmeg) promoted more $24-\mathrm{h}{ }^{59} \mathrm{Fe}$ excretion than the tetradentate ligand 5LIO(TAMmeg); similarly, when administered in the same conditions (dose level, ip injection or oral gavage) the octadentate chelator 3,4,3-LI(1,2-HOPO) was more efficient at removing ${ }^{238} \mathrm{Pu}$ and ${ }^{241} \mathrm{Am}$ from mice than the tetradentate ligand 5-LIO(Me-3,2-HOPO). These results therefore 
indicate that the higher stability of complexes formed with higher denticity ligands and $\mathrm{Fe}, \mathrm{Pu}$ or Am is rendered into in vivo chelating efficacy.

Both DFO and DTPA have been available for decades as iron and actinide chelators, respectively, and are still the current treatments of choice, despite the vast research effort dedicated to new chelation therapies. However, poor patient compliance to continuous DFO therapy and logistic difficulties of administering DTPA to large populations are inevitable consequences of the lack of oral activity of these drug products. The design and development of new chelators must therefore be focused on orally active compounds. While the large molecular weights (often $>500 \mathrm{~g} \mathrm{~mol}^{-1}$ ) associated to multidentate metal-chelating agents have often been considered a discriminating factor for pharmaceutical applications (11), another objective of this work is to demonstrate that the high metal-affinity of multidentate ligands can compensate for their lower bioavailability. The respective actinide-chelating efficacies of 3,4,3-LI(1,2-HOPO) and 5-LIO(Me-3,2-HOPO) were evaluated using both ip injection and oral gavage as administration ways. As expected, the ligands promoted more actinide excretion when injected at equal injection and oral doses (30 $\mu \mathrm{mol} \mathrm{kg} \mathrm{kg}^{-1}$ for 3,4,3-LI(1,2-HOPO); $100 \mu \mathrm{mol} \mathrm{kg} \mathrm{kg}^{-1}$ for 5LIO(Me-3,2-HOPO)); however, both ligands still promoted significant actinide removal when administered orally. In addition, higher oral doses permit to reach excretion levels similar to those obtained with low injection doses (19); these higher doses $\left(100 \mu \mathrm{mol} \mathrm{kg}^{-1}\right.$ for 3,4,3-LI(1,2HOPO); $200 \mu \mathrm{mol} \mathrm{kg}^{-1}$ for 5-LIO(Me-3,2-HOPO)) are well within the ranges of standard daily doses used in current chelation therapies $\left(30 \mu \mathrm{mol} \mathrm{kg}{ }^{-1}\right.$ for DTPA; $50-100 \mu \mathrm{mol} \mathrm{kg} \mathrm{kg}^{-1}$ for DFO and ICL670A; 500-700 $\mu \mathrm{mol} \mathrm{kg}^{-1}$ for L1). Despite their larger molecular weights and resulting lower bioavailability, high-denticity ligands with high affinities for targeted metals can therefore act as efficacious orally active chelators. 


\section{CONCLUSION}

Radioactive tracers $\left({ }^{59} \mathrm{Fe},{ }^{238} \mathrm{Pu}\right.$, and $\left.{ }^{241} \mathrm{Am}\right)$ were used in mice to evaluate two series of multidentate ligands incorporating several 2,3-dihydroxy-terephthalamide and hydroxypyridinone metal-binding units for their in vivo efficacy at removing iron and actinides, respectively. These chelators coordinate the targeted metal ions with high thermodynamic stability, and were found to promote higher levels of iron and actinide excretion than the current commonly used therapeutic agents DFO and DTPA, respectively, at comparable doses and independently of the experimental protocol. The efficacy of the ligands increased with their denticity within each series. In addition, significant excretion levels were obtained for octadentate and tetradentate actinide chelators administered orally. These results provide a rational basis for the design of new orally available therapeutic multidentate metal sequestering agents. Supplemental biological evaluations of the discussed ligands, including the establishment of (i) efficacy profiles in other animal models, (ii) toxicity and pharmacokinetic profiles and (iii) therapeutic indices, are in progress and will lay the foundations for further clinical development.

\section{ACKNOWLEDGMENTS}

This work was supported by National Institutes of Health grants 1RC2AI087604-01 (KNR, RJA) and DK057814 (KNR), a Cooley's Anemia Foundation Young Investigator Fellowship (RJA), and the Director, Office of Science, Office of Basic Energy Sciences, Division of Chemical Sciences, Geosciences, and Biosciences of the U.S. Department of Energy at Lawrence Berkeley National Laboratory under Contract No. DE-AC02-05CH11231. 


\section{REFERENCES}

1. Andrews NC. Disorders of iron metabolism. N Eng J Med 1999; 341(26):1986-1995.

2. Durbin PW. Lauriston S. Taylor lecture: The quest for therapeutic actinide chelators. Health Phys 2008; 95(5):465-492.

3. Scott LE, Orvig C. Medicinal inorganic chemistry approaches to passivation and removal of aberrant metal ions in disease. Chem Rev 2009; 109:4885-4910.

4. Hershko C. Oral iron chelators: New opportunities and new dilemmas. Haematol 2006; 91(10):1307-1312.

5. Roberts DJ, Rees D, Howard J, Hyde C, Alderson P, Brunskill S. Desferrioxamine mesylate for managing transfusional iron overload in people with transfusion-dependent thalassaemia. Cochrane Database of Systematic Reviews 2005; (4).

6. Durbin PW, Actinides in animals and man, in The chemistry of the actinide and transactinide elements, Morss LR, Edelstein NM, Fuger J, Editors. 2006, Springer Netherlands. p. 3339-3440.

7. Roberts DJ, Brunskill SJ, Doree C, Williams S, Howard J, Hyde CJ. Oral deferiprone for iron chelation in people with thalassaemia. Cochrane Database of Systematic Reviews 2007; (3).

8. Neufeld EJ. Oral chelators deferasirox and deferiprone for transfusional iron overload in thalassemia major: New data, new questions. Blood 2006; 107(9):3436-3441.

9. Porter JB. Deferasirox: An effective once-daily orally active iron chelator. Drugs of Today 2006; 42(10):623-637. 
10. Kontoghiorghes GJ. Response to the letter to the editor: Transparency and access to full information for the fatal or serious toxicity risks, low efficacy and high price of deferasirox, could increase the prospect of improved iron chelation therapy worldwide. Hemoglobin 2008; 32(6):608-615.

11. Hider RC, Zhou T. The design of orally active iron chelators. Ann N Y Acad Sci 2005; 1054:141-154.

12. Kalinowski DS, Richardson DR. The evolution of iron chelators for the treatment of iron overload disease and cancer. Pharmacol Rev 2005; 57(4):547-583.

13. Rivkin G, Link G, Simhon E, Cyjon RL, Klein JY, Hershko C. Irc011, a new synthetic chelator with selective interaction with catabolic red blood cell iron: Evaluation in hypertransfused rats with hepatocellular and reticuloendothelial radioiron probes and in iron-loaded rat heart cells in culture. Blood 1997; 90(10):4180-4187.

14. Lipinski CA, Lombardo F, Dominy BW, Feeney PJ. Experimental and computational approaches to estimate solubility and permeability in drug discovery and development settings. Adv Drug Deliv Rev 2001; 46(1-3):3-26.

15. Abergel RJ, Raymond KN. Synthesis and thermodynamic evaluation of mixed hexadentate linear iron chelators containing hydroxypyridinone and terephthalamide units. Inorg Chem 2006; 45(9):3622-3631.

16. Abergel RJ, Raymond KN. Terephthalamide-containing ligands: Fast removal of iron from transferrin. J Biol Inorg Chem 2008; 13:229-240.

17. Jurchen KMC, Raymond KN. A bidentate terephthalamide ligand, tammeg, as an entry into terephthalamide-containing therapeutic iron chelating agents. Inorg Chem 2006; 45:2438-2447. 
18. Jurchen KMC, Raymond KN. Terephtalamide-containing analogs of tren-me-3,2-hopo. Inorg Chem 2006; 45:1078-1090.

19. Abergel RJ, Durbin PW, Kullgren B, Ebbe SN, Xu J, Chang PY, Bunin DI, Blakely EA, Bjornstad KA, Rosen CJ, D.K. S, Raymond KN. Biomimetic actinide chelators: An update on the preclinical development of the orally active hydroxypyridonate decorporation agents 3,4,3-LI(1,2-HOPO) and 5-LIO(Me-3,2-HOPO). Health Phys 2010; 99(3):In press.

20. Durbin PW, Jeung N, Kullgren B, Clemons GK. Gross composition and plasma and extracellular water volumes of tissues of a reference mouse. Health Phys 1992; 63:427442.

21. Durbin $\mathrm{PW}$, Kullgren $\mathrm{B}, \mathrm{Xu} \mathrm{J}$, Raymond $\mathrm{KN}$. In vivo chelation of $\mathrm{Am}(\mathrm{III}), \mathrm{Pu}(\mathrm{IV})$, $\mathrm{Np}(\mathrm{V})$, and $\mathrm{U}(\mathrm{VI})$ in mice by TREN(Me-3,2-HOPO). Radiat Prot Dosim 1994; 53:305309.

22. Durbin PW, Kullgren B, Xu J, Raymond KN. Multidentate hydroxypyridonate ligands for $\mathrm{Pu}(\mathrm{IV})$ chelation in vivo: Comparative efficacy and toxicity in mouse of ligands containing 1,2-HOPO or Me-3,2-HOPO. Int J Rad Biol 2000; 76:199-214.

23. Raymond KN, Telford JR, Siderophore-mediated iron transport in microbes, in Bioinorganic chemistry an inorganic perspective of life, Kessissoglou DP, Editor. 1995, Kluwer Academic Publishers: The Netherlands. p. 25-37.

24. Evers A, Hancock RD, Martell AE, Motekaitis RJ. Metal-ion recognition in ligands with negatively charged oxygen donor groups - complexation of Fe(III), Ga(III), In(III), Al(III), and other highly charged metal-ions. Inorg Chem 1989; 28(11):2189-2195. 
25. Heinz U, Hegetschweiler K, Acklin P, Faller B, Lattmann R, Schnebli HP. 4-[3,5-bis(2hydroxyphenyl)-1,2,4-triazol-1-yl]- benzoic acid: A novel efficient and selective iron(III) complexing agent. Angew Chem Int Ed 1999; 38(17):2568-2570.

26. Ma R, Reibenspies JJ, Martell AE. Stabilities of 1,2-diethyl-3-hydroxy-4-pyridinone chelates of divalent and trivalent metal-ions. Inorg Chim Acta 1994; 223(1-2):21-29.

27. Mack C, Essential of statistics for scientists and technologists. 1967, New york: Plenum Press. 


\section{FIGURES}
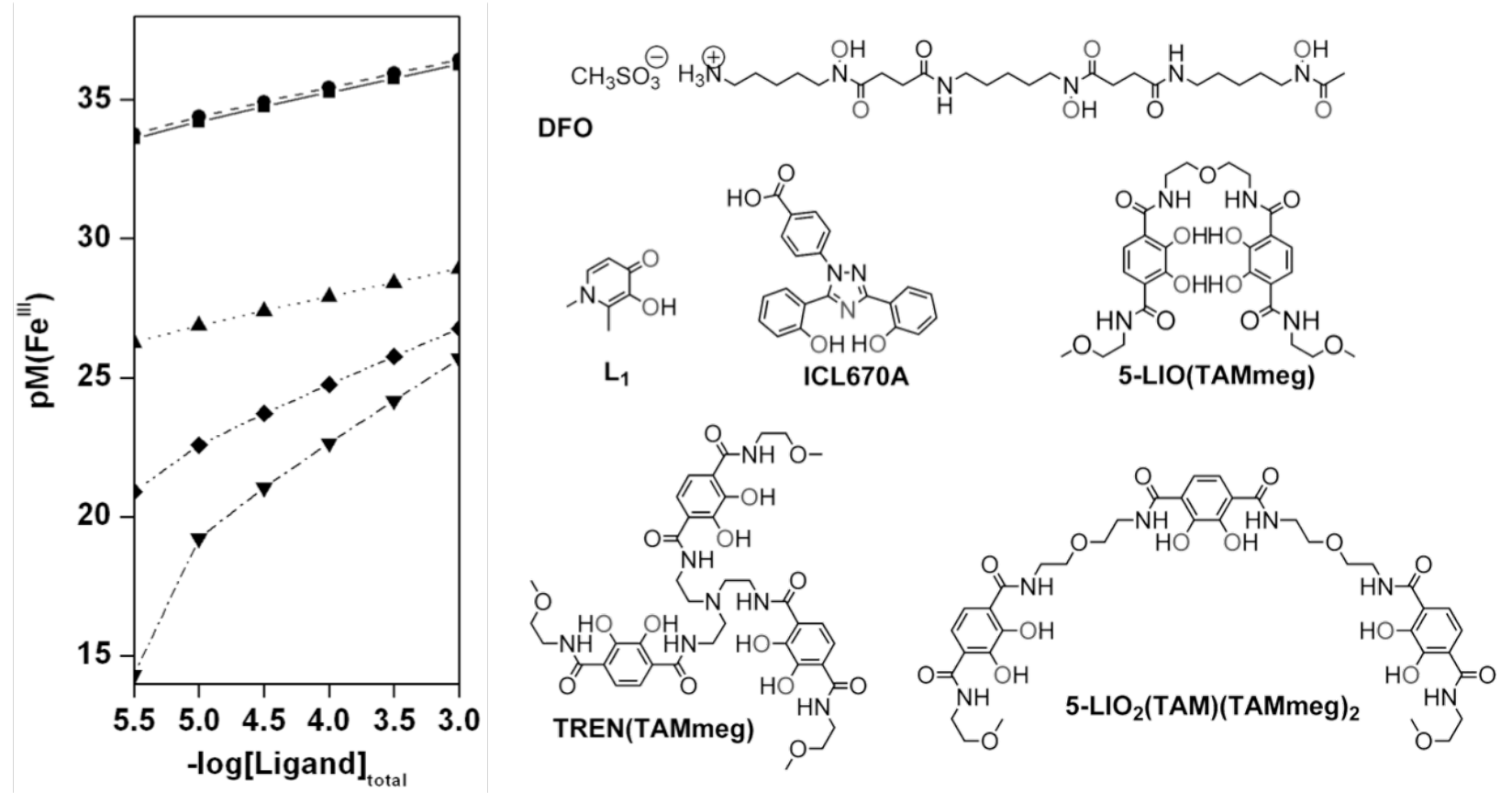

Figure 1. Left: Concentration dependence for iron complexation as a result of denticity by iron chelators L1 ( $\boldsymbol{\nabla}$, bidentate), ICL670A $(\bullet$, tridentate), DFO ( $\boldsymbol{\Delta}$, hexadentate), TREN(TAMmeg)

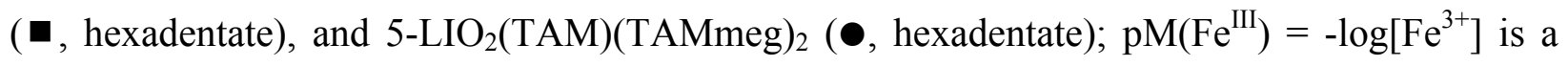
direct measure of complex stability; the calculations are for varying ligand concentration with a constant $1 \times 10^{-6} \mathrm{M}$ total iron at $\mathrm{pH} 7.4$ and are based on reported stability constants $(15,18,24$ 26). Right: Molecular structures of discussed iron chelators. 

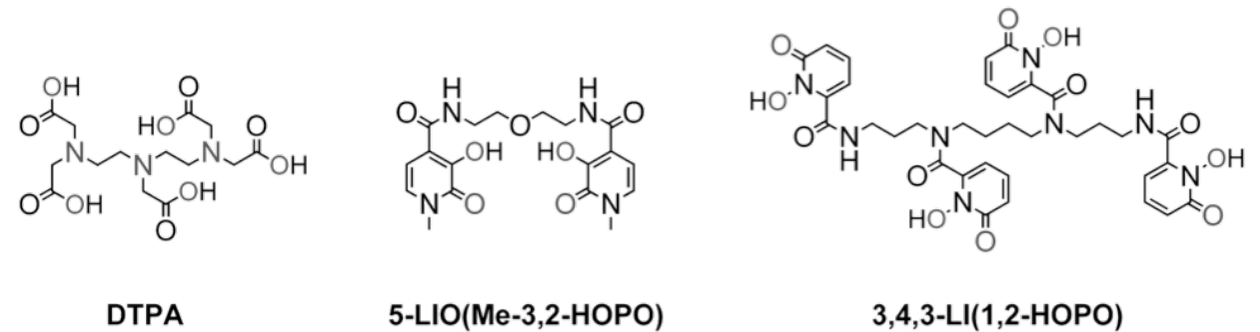

5-LIO(Me-3,2-HOPO)

3,4,3-LI(1,2-HOPO)

Figure 2. Molecular structures of discussed actinide chelators. 


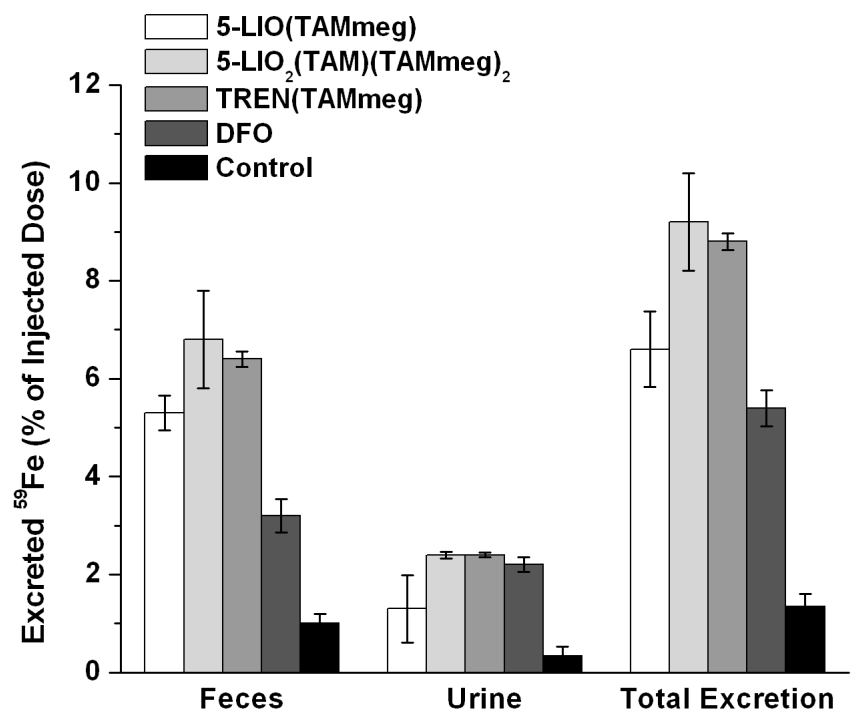

Figure 3. Excreted ${ }^{59} \mathrm{Fe}$ promoted by injected chelators. Normal mice injected iv with ${ }^{59} \mathrm{Fe}-\mathrm{Tf}$; ligands $\left(100 \mu \mathrm{mol} \mathrm{kg}{ }^{-1}\right)$ injected ip 30 min later; mice euthanized at $24 \mathrm{~h}$. Excreta of each fivemouse group were pooled, uncertainties were determined from the standard deviation between three groups for 5-LIO 2 (TAM)(TAMmeg) 2 , TREN(TAMmeg), DFO, and controls, and two groups for 5-LIO(TAMmeg). 


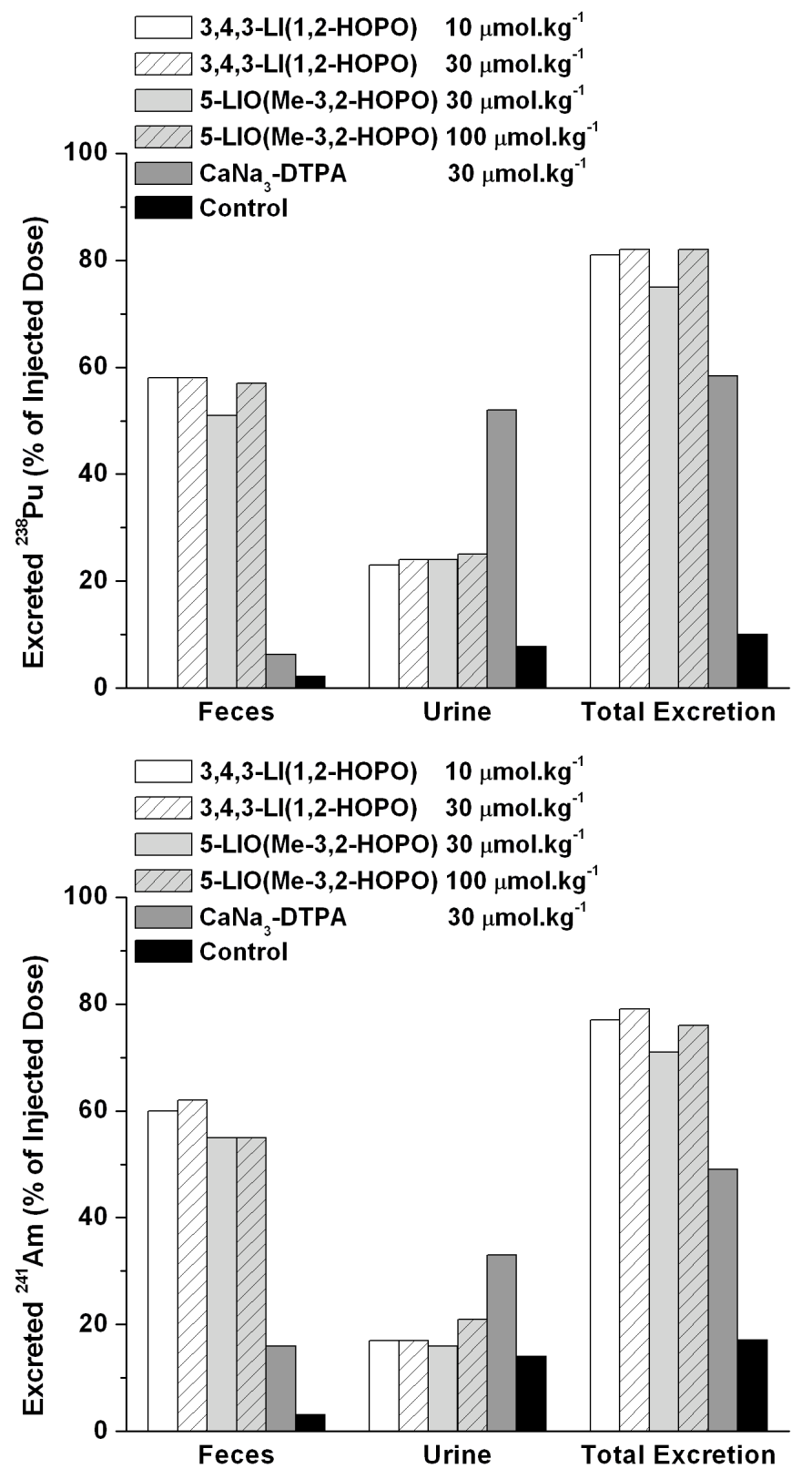

Figure 4. Excreted ${ }^{238} \mathrm{Pu}$ (top) and ${ }^{241} \mathrm{Am}$ (bottom) promoted by injected chelators. Normal mice injected iv with ${ }^{238} \mathrm{Pu}$ or ${ }^{241} \mathrm{Am}$; ligands (10 $\mu \mathrm{mol} \mathrm{kg}{ }^{-1} 3,4,3-\mathrm{LI}(1,2-\mathrm{HOPO})$ and $30 \mu \mathrm{mol} \mathrm{kg}{ }^{-1}$ LIO(Me-3,2-HOPO)) injected ip $1 \mathrm{~h}$ later; mice euthanized at $24 \mathrm{~h}$. Excreta of each five-mouse group were pooled and standard deviations are not available. Excretion data for $30 \mu \mathrm{mol} \mathrm{\textrm {kg } ^ { - 1 }}$ 3,4,3-LI(1,2-HOPO), $30 \mu \mathrm{mol} \mathrm{kg}{ }^{-1}$ DTPA, and $100 \mu \mathrm{mol} \mathrm{kg}^{-1}$ 5-LIO(Me-3,2-HOPO) determined previously (19) and shown here for comparison purposes. 

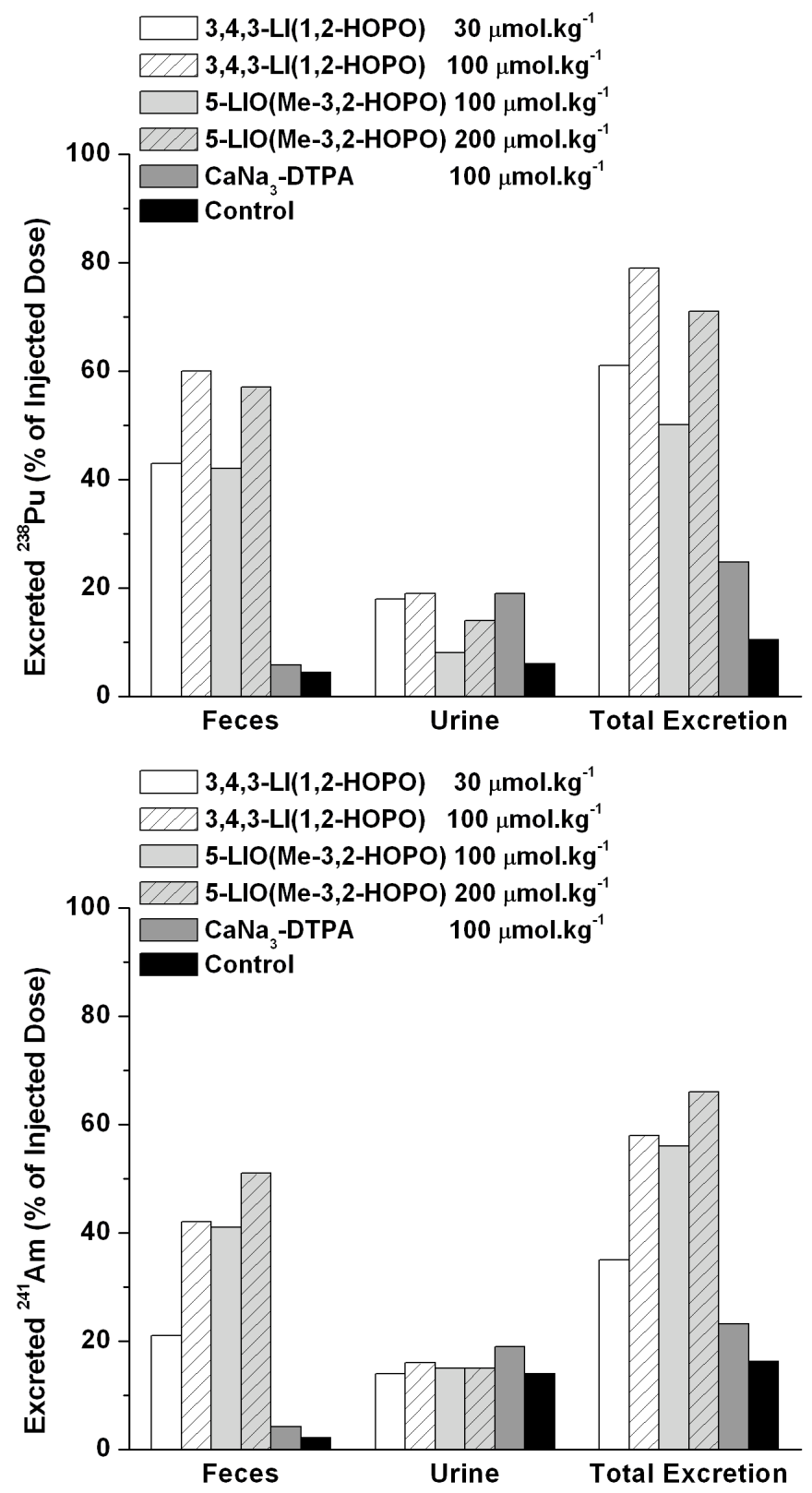

Figure 5. Excreted ${ }^{238} \mathrm{Pu}$ (top) and ${ }^{241} \mathrm{Am}$ (bottom) promoted by orally administered chelators. Normal mice injected iv with ${ }^{238} \mathrm{Pu}$ or ${ }^{241} \mathrm{Am}$; ligands (30 $\mu \mathrm{mol} \mathrm{kg}{ }^{-1} 3,4,3-\mathrm{LI}(1,2-\mathrm{HOPO})$ and 100 $\mu \mathrm{mol} \mathrm{kg}{ }^{-1}$ 5-LIO(Me-3,2-HOPO)) given by gastric intubation $1 \mathrm{~h}$ later; mice euthanized at $24 \mathrm{~h}$. Excreta of each five-mouse group were pooled and standard deviations are not available. Excretion data for $100 \mu \mathrm{mol} \mathrm{kg}{ }^{-1} 3,4,3-\mathrm{LI}(1,2-\mathrm{HOPO}), 100 \mu \mathrm{mol} \mathrm{kg}{ }^{-1}$ DTPA, and $200 \mu \mathrm{mol} \mathrm{kg}^{-1}$ 5-LIO(Me-3,2-HOPO) determined previously (19) and shown here for comparison purposes. 


\section{TABLES}

\begin{tabular}{|c|c|c|c|c|c|c|}
\hline \multirow[b]{2}{*}{ Ligand } & \multirow[b]{2}{*}{ No. of mice } & \multicolumn{5}{|c|}{ Fraction of injected ${ }^{59} \mathrm{Fe}(\%$, mean $\pm \mathrm{SD})$ at $24 \mathrm{~h}^{b}$} \\
\hline & & Liver & Kidneys & GI Tract (full) & Carcass $^{c}$ & Whole Body \\
\hline 5-LIO(TAMmeg) & 10 & $9.6 \pm 1.5^{d}$ & $1.3 \pm 0.12^{d}$ & $9.9 \pm 1.9$ & $73 \pm 3.0$ & $93 \pm 1.0^{e}$ \\
\hline $5-\mathrm{LIO}_{2}(\mathrm{TAM})(\mathrm{TAMmeg})_{2}$ & 15 & $7.0 \pm 0.86^{d, e}$ & $1.4 \pm 0.12^{d}$ & $8.5 \pm 1.3$ & $74 \pm 2.9$ & $91 \pm 1.7^{d, e}$ \\
\hline TREN(TAMmeg) & 15 & $7.4 \pm 1.1^{d, e}$ & $1.4 \pm 0.17^{d}$ & $8.5 \pm 2.1$ & $74 \pm 1.8$ & $91 \pm 1.0^{d, e}$ \\
\hline DFO & 15 & $9.1 \pm 1.9^{d}$ & $1.4 \pm 0.18^{d}$ & $8.6 \pm 1.5$ & $75 \pm 3.8$ & $94 \pm 1.9^{d}$ \\
\hline Treatment controls & 15 & $12 \pm 2.3$ & $1.7 \pm 0.19$ & $9.5 \pm 1.6$ & $76 \pm 3.9$ & $99 \pm 1.0$ \\
\hline
\end{tabular}

Table 1. Distribution of ${ }^{59} \mathrm{Fe}$ in tissues from mice labeled with ${ }^{59} \mathrm{Fe}$-Tf and subsequently injected with multidentate terephthalamide-containing ligands. ${ }^{a}$

${ }^{a}$ Groups of five mice were injected iv with ${ }^{59} \mathrm{Fe}$-labeled mouse plasma; mice were injected ip with $100 \mu \mathrm{mol} \mathrm{kg}{ }^{-1}$ of a ligand at $30 \mathrm{~min}$; control mice were given $0.14 \mathrm{M} \mathrm{NaCl}$ (normal saline) ip; mice were euthanized at $24 \mathrm{~h}$.

${ }^{b}$ Data, expressed as percent of injected ${ }^{59} \mathrm{Fe}(\%$, mean \pm standard deviation SD), were normalized to $100 \%$ material recovery for each five-mouse group. Discrepancies are due to rounding. $\mathrm{SD}=$ $\left[\Sigma \operatorname{dev}^{2}(\mathrm{n}-1)^{-1}\right]^{1 / 2}$; for tissues, $\mathrm{n}=$ number of mice.

${ }^{c}$ Carcass is skeleton, blood sample, and all soft tissue except liver, kidneys and GI tract (full).

${ }^{d}$ Mean is significantly less than for the control mice (t-test, $\mathrm{p} \leq 0.01$ (27)).

${ }^{e}$ Mean is significantly less than for mice similarly treated with DFO (t-test, $\mathrm{p} \leq 0.01(27)$ ). 


\begin{tabular}{|c|c|c|c|c|c|c|}
\hline \multirow[b]{2}{*}{ Ligand } & \multirow[b]{2}{*}{ Protocol } & \multicolumn{5}{|c|}{ Fraction of injected ${ }^{238} \mathrm{Pu}(\%$, mean $\pm \mathrm{SD})$ at $24 \mathrm{~h}^{b}$} \\
\hline & & Liver & Kidneys & Soft Tissues & Skeleton & Whole Body \\
\hline \multirow[t]{2}{*}{ 3,4,3-LI(1,2-HOPO) } & 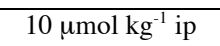 & $3.7 \pm 1.7^{\mathrm{c}, \mathrm{d}}$ & $0.3 \pm 0.1^{\mathrm{c}, \mathrm{d}}$ & $3.1 \pm 0.6^{\mathrm{c}, \mathrm{d}}$ & $12 \pm 0.8^{\mathrm{c}, \mathrm{d}}$ & $20 \pm 2.1^{\mathrm{c}, \mathrm{d}}$ \\
\hline & $30 \mu \mathrm{mol} \mathrm{kg}{ }^{-1}$ po & $19 \pm 5.8^{\mathrm{c}, \mathrm{d}}$ & $0.6 \pm 0.3^{\mathrm{c}, \mathrm{d}}$ & $3.1 \pm 1.4^{\mathrm{c}, \mathrm{d}}$ & $21 \pm 6.6^{\mathrm{c}}$ & $38 \pm 11^{\mathrm{c}, \mathrm{d}}$ \\
\hline \multirow[t]{2}{*}{ 5-LIO(Me-3,2-HOPO) } & 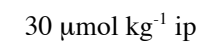 & $4.9 \pm 3.2^{\mathrm{c}, \mathrm{d}}$ & $0.5 \pm 0.2^{\mathrm{c}}$ & $3.8 \pm 0.7^{\mathrm{c}, \mathrm{d}}$ & $16 \pm 0.9^{c}$ & $25 \pm 3.5^{\mathrm{c}, \mathrm{d}}$ \\
\hline & $100 \mu \mathrm{mol} \mathrm{kg}{ }^{-1}$ po & $14 \pm 6.2^{\mathrm{c}, \mathrm{d}}$ & $0.7 \pm 0.3^{\mathrm{c}}$ & $4.6 \pm 0.8^{\mathrm{c}, \mathrm{d}}$ & $30 \pm 6.5^{\mathrm{c}}$ & $50 \pm 11^{\mathrm{c}, \mathrm{d}}$ \\
\hline \multirow[t]{2}{*}{$\mathrm{CaNa}_{3}$-DTPA } & $30 \mu \mathrm{mol} \mathrm{kg}{ }^{-1} \mathrm{ip}^{\mathrm{e}}$ & $21 \pm 6.9^{\mathrm{c}}$ & $0.8 \pm 0.2^{\mathrm{c}}$ & $5.3 \pm 0.6^{\mathrm{c}}$ & $15 \pm 1.5^{\mathrm{c}}$ & $41 \pm 6.5^{\mathrm{c}}$ \\
\hline & $100 \mu \mathrm{mol} \mathrm{kg}{ }^{-1} \mathrm{po}^{\mathrm{e}}$ & $40 \pm 3.5$ & $1.2 \pm 0.3$ & $6.4 \pm 0.9$ & $28 \pm 3.5$ & $75 \pm 4.8^{c}$ \\
\hline \multirow[t]{2}{*}{ Treatment controls } & saline $\mathrm{ip}^{\mathrm{e}}$ & $34 \pm 1.4$ & $1.5 \pm 0.2$ & $9.7 \pm 2.5$ & $45 \pm 3.1$ & $90 \pm 1.8$ \\
\hline & saline $\mathrm{po}^{\mathrm{e}}$ & $45 \pm 2.6$ & $1.7 \pm 0.4$ & $6.6 \pm 1.4$ & $36 \pm 4.7$ & $90 \pm 1.6$ \\
\hline
\end{tabular}

Table 2. Distribution of ${ }^{238} \mathrm{Pu}$ in tissues from mice injected with ${ }^{238} \mathrm{Pu}$ and subsequently given multidentate hydroxypyridinone-containing ligands. ${ }^{a}$

${ }^{a}$ Groups of five mice were injected iv with ${ }^{238} \mathrm{Pu}$; ligands were given by ip injection $\left(10 \mu \mathrm{mol} \mathrm{kg}{ }^{-}\right.$ ${ }^{1}$ for 3,4,3-LI(1,2-HOPO), $30 \mu \mathrm{mol} \mathrm{kg}{ }^{-1}$ for 5-LIO(Me-3,2-HOPO)) or gastric intubation (30 $\mu \mathrm{mol} \mathrm{kg}{ }^{-1}$ oral for 3,4,3-LI(1,2-HOPO), $100 \mu \mathrm{mol} \mathrm{kg}^{-1}$ for 5 -LIO(Me-3,2-HOPO)) at $1 \mathrm{~h}$ after iv injection of the actinide, and were euthanized at $24 \mathrm{~h}$. Orally treated mice were fasted from $16 \mathrm{~h}$ before to $4 \mathrm{~h}$ after the actinide injection.

${ }^{b}$ Data, expressed as percent of injected actinide (\% ID, mean \pm SD), were normalized to $100 \%$ material recovery for each five-mouse group. Discrepancies are due to rounding. $\mathrm{SD}=\left[\Sigma \mathrm{dev}^{2}\right.$ $\left.(\mathrm{n}-1)^{-1}\right]^{1 / 2}$; for tissues, $\mathrm{n}=$ number of mice $(5$ mice, 1 group for each protocol).

${ }^{c}$ Mean is significantly less than for the similarly treated control mice (t-test, $\mathrm{p} \leq 0.01(27)$ ).

${ }^{d}$ Mean is significantly less than for mice similarly treated with $\mathrm{CaNa}_{3}$-DTPA (t-test, $\mathrm{p} \leq 0.01$ (27)).

${ }^{e}$ Data previously reported and shown here for comparison purposes (19). 


\begin{tabular}{|c|c|c|c|c|c|c|}
\hline \multirow[b]{2}{*}{ Ligand } & \multirow[b]{2}{*}{ Protocol } & \multicolumn{5}{|c|}{ Fraction of injected ${ }^{241} \mathrm{Am}(\%$, mean $\pm \mathrm{SD})$ at $24 \mathrm{~h}^{b}$} \\
\hline & & Liver & Kidneys & Soft Tissues & Skeleton & Whole Body \\
\hline \multirow[t]{2}{*}{$3,4,3-\mathrm{LI}(1,2-\mathrm{HOPO})$} & 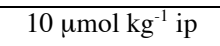 & $4.4 \pm 1.4^{\mathrm{c}, \mathrm{d}}$ & $0.4 \pm 0.1^{\mathrm{c}, \mathrm{d}}$ & $4.5 \pm 0.6^{\mathrm{c}, \mathrm{d}}$ & $14 \pm 0.5^{\mathrm{c}, \mathrm{d}}$ & $24 \pm 1.7^{\mathrm{c}, \mathrm{d}}$ \\
\hline & $30 \mu \mathrm{mol} \mathrm{kg}{ }^{-1}$ po & $37 \pm 8.7^{\mathrm{c}, \mathrm{d}}$ & $0.6 \pm 0.1^{\mathrm{c}}$ & $4.2 \pm 0.6^{\mathrm{c}, \mathrm{d}}$ & $23 \pm 1.2^{\mathrm{c}}$ & $65 \pm 8.7^{\mathrm{c}, \mathrm{d}}$ \\
\hline \multirow[t]{2}{*}{ 5-LIO(Me-3,2-HOPO) } & $30 \mu \mathrm{mol} \mathrm{kg}{ }^{-1}$ ip & $5.6 \pm 0.4^{\mathrm{c}, \mathrm{d}}$ & $0.4 \pm 0.1^{\mathrm{c}, \mathrm{d}}$ & $5.3 \pm 0.5^{\mathrm{c}, \mathrm{d}}$ & $18 \pm 1.8^{\mathrm{c}}$ & $29 \pm 2.2^{\mathrm{c}, \mathrm{d}}$ \\
\hline & $100 \mu \mathrm{mol} \mathrm{kg}{ }^{-1}$ po & $15 \pm 4.4^{\mathrm{c}, \mathrm{d}}$ & $0.6 \pm 0.1^{\mathrm{c}}$ & $5.0 \pm 0.5^{\mathrm{c}}$ & $24 \pm 2.1^{\mathrm{c}}$ & $45 \pm 2.5^{\mathrm{c}, \mathrm{d}}$ \\
\hline \multirow[t]{2}{*}{$\mathrm{CaNa}_{3}$-DTPA } & $30 \mu \mathrm{mol} \mathrm{kg}{ }^{-1} \mathrm{ip}^{\mathrm{e}}$ & $24 \pm 2.0^{\mathrm{c}}$ & $0.6 \pm 0.1^{\mathrm{c}}$ & $6.3 \pm 0.2$ & $20 \pm 1.4^{\mathrm{c}}$ & $50 \pm 0.9^{\mathrm{c}}$ \\
\hline & $100 \mu \mathrm{mol} \mathrm{kg}{ }^{-1} \mathrm{po}^{\mathrm{e}}$ & $49 \pm 3.6$ & $0.7 \pm 0.1$ & $5.0 \pm 0.3$ & $22 \pm 2.0^{\mathrm{c}}$ & $77 \pm 2.7^{\mathrm{c}}$ \\
\hline \multirow[t]{2}{*}{ Treatment controls } & saline $\mathrm{ip}^{\mathrm{e}}$ & $49 \pm 1.0$ & $0.9 \pm 0.1$ & $7.1 \pm 0.8$ & $26 \pm 1.9$ & $83 \pm 1.7$ \\
\hline & saline po $^{\mathrm{e}}$ & $49 \pm 1.5$ & $1.1 \pm 0.5$ & $5.9 \pm 0.9$ & $28 \pm 1.6$ & $83 \pm 2.2$ \\
\hline
\end{tabular}

Table 3. Distribution of ${ }^{241} \mathrm{Am}$ in tissues from mice injected with ${ }^{241} \mathrm{Am}$ and subsequently given multidentate hydroxypyridinone-containing ligands. ${ }^{a}$

${ }^{a}$ Groups of five mice were injected iv with ${ }^{241} \mathrm{Am}$; ligands were given by ip injection (10 $\mu \mathrm{mol}$ $\mathrm{kg}^{-1}$ for 3,4,3-LI(1,2-HOPO), $30 \mu \mathrm{mol} \mathrm{kg} \mathrm{kg}^{-1}$ for 5-LIO(Me-3,2-HOPO)) or gastric intubation (30 $\mu \mathrm{mol} \mathrm{kg}{ }^{-1}$ oral for 3,4,3-LI(1,2-HOPO), $100 \mu \mathrm{mol} \mathrm{kg}{ }^{-1}$ for 5-LIO(Me-3,2-HOPO)) at $1 \mathrm{~h}$ after iv injection of the actinide, and were euthanized at $24 \mathrm{~h}$. Orally treated mice were fasted from $16 \mathrm{~h}$ before to $4 \mathrm{~h}$ after the actinide injection.

${ }^{b}$ Data, expressed as percent of injected actinide (\% ID, mean \pm SD), were normalized to $100 \%$ material recovery for each five-mouse group. Discrepancies are due to rounding. $\mathrm{SD}=\left[\Sigma \mathrm{dev}^{2}\right.$ $\left.(n-1)^{-1}\right]^{1 / 2}$; for tissues, $\mathrm{n}=$ number of mice $(5$ mice, 1 group for each protocol $)$.

${ }^{c}$ Mean is significantly less than for the similarly treated control mice (t-test, $\mathrm{p} \leq 0.01(27)$ ).

${ }^{d}$ Mean is significantly less than for mice similarly treated with $\mathrm{CaNa}_{3}$-DTPA (t-test, $\mathrm{p} \leq 0.01$ (27)).

${ }^{e}$ Data previously reported and shown here for comparison purposes (19). 